\title{
BERASTAGI HOTEL RESORT DESIGN (NEO-VERNACULAR ARCHITECTURE DESIGN APPROACH)
}

\author{
Andre Sebayang ${ }^{1}$, Morida Siagian 1 \\ 1. Architecture Department, Faculty of Engineering, Universitas Sumatera Utara, Medan, \\ Indonesia \\ Jl. Perpustakaan St. J07 Building, Medan, 20155, Indonesia \\ *Email: sebayang1995@gmail.com
}

\begin{abstract}
Berastagi is one of the tourist destinations in North Sumatera. The increasing number of tourists visiting and lodging is lacking. Therefore adequate it is required for the convenience of tourists. Hotel Resort Berastagi can accommodate so that the tourists who stay in Berastagi can feel and enjoy the beauty of Berastagi. The methodology used is collecting data by field survey, interview, literature, and comparative study. The results of the analysis will be processed into design and planning concepts in measurable working drawings. With a threestar hotel classification, the number of rooms is 100, and five different types of them can accommodate the visitors. The hotel also allows recreational facilities that are comfortable and appealing for them such as, swimming pool, meeting areas, and sports Centre areas. Addition, to enjoying the beauty of Berastagi, this hotel is also allowed to introduce the charm Karo Tribe culture. To keep the cultural tour, the hotel applies the theme of Neo-Vernacular Architecture. The concept used is from the Siwaluh Jabu Traditional House, namely the Karo House which is designed to keep up with the modernization of the current era so that it is not considered outdated. By applying the theme, This Hotel is expected to preserve local culture. Other than that the hotel can provide a special attraction for the tourists who visit Berastagi..
\end{abstract}

Keywords: architecture, Berastagi, hotel resort, neo-vernacular, Siwaluh Jabu.

\section{INTRODUCTION}

Boredom and fatigue caused by daily routine will necessarily require time to take a break for everyone. Traveling and enjoying the beauty of creation of the Almighty and studying the various types uniqueness of ethnic groups in Indonesia can be an option to eliminate the boredom and fatigue for a moment. So it cannot be denied the tourism sector became one of the most sources of cash receipts regions or countries. With the development of the tourism sector, it will be expected that others will be growing as well, including in the areas of lodging and hospitality. So those, the number of it around the locations that have tourist destinations need to be improved.

North Sumatera has many tourist destinations. In addition to the natural beauty, this province also has various types of tribes that have its privileges. Berastagi is one of the many tourist destinations in North Sumatra Province. The natural beauty of Berastagi is the main attraction for tourists. In this place, we can see the beautiful views of the mountain range and Medan City from an altitude of 1300 meters above the sea level (MASL). The atmosphere is still cold and away from the urban noise makes this place worthy of being a tourist destination for domestic and foreign tourists.

Currently, the number of lodging and recreation areas in Berastagi has not been supportive of tourists who will travel to this place. To resolve that, it is required a safe and comfortable accommodation that has recreational facilities that support the tourists to enjoy the natural beauty of Berastagi. In addition to it, the design of the place can also maintain the existing local cultural wisdom. Berastagi is very synonymous with The Karo Culture. Almost 90\% of the population in Berastagi is the Karo tribe and communicates in Karo language. It is a potential for cultural tourism in Berastagi. Thus, by providing an area for cultural tourism, local wisdom of Berastagi will be a sustainable and especially attraction for visitors. 


\section{LITERATURE REVIEW}

\section{Terminology}

According to Richard H. Penner, Design was decided upon the look and functioning of a building, garment, or another object, by making a detailed drawing of it [1]. Meanwhile, according to Indonesian dictionary, Hotel is an establishment providing accommodation, meals, and other services for travelers and tourists. According to Indonesian dictionary, Resort is a place that is frequented by them for holidays or recreations. And Berastagi is a sub-district in Karo District, North Sumatera. Thus by definition, Berastagi Hotel Resort Design is the result of the design to make a place of accommodation as a tourist facility located in Berastagi.

\section{The Elaboration of Theme}

The design theme is the Neo-Vernacular Architecture. The design process will readopting the original architecture by transforming/updating the physical and nonphysical appearance. Located in Berastagi, so the concept used is the Karo Vernacular Architecture. The difference between NeoVernacular and Vernacular and Traditional can be seen in Table 1 [2].

Table 1. Comparison of the Differences Traditional, Vernacular, and Neo-Vernacular

\begin{tabular}{|c|c|c|c|}
\hline $\begin{array}{c}\text { Comparis } \\
\text { on }\end{array}$ & Traditional & Vernakular & Neo Vernacular \\
\hline Ideology & $\begin{array}{l}\text { Formed by traditions } \\
\text { inherited from generation } \\
\text { to generation, based on } \\
\text { local culture and } \\
\text { conditions. }\end{array}$ & $\begin{array}{l}\text { Formed by hereditary } \\
\text { traditions but there are } \\
\text { influences from both } \\
\text { physical and non-physical, } \\
\text { forms of development of } \\
\text { traditional architecture. }\end{array}$ & $\begin{array}{l}\text { The application of existing } \\
\text { architectural elements and } \\
\text { then little or much } \\
\text { experience of renewal } \\
\text { towards a modern work. }\end{array}$ \\
\hline Prinsip & $\begin{array}{l}\text { Closed from the changing } \\
\text { times, adhered to one } \\
\text { regional culture, and has } \\
\text { strong religious rules and } \\
\text { norms }\end{array}$ & $\begin{array}{l}\text { Develop every time to } \\
\text { reflect the environment, } \\
\text { culture, and history of the } \\
\text { area where the } \\
\text { architecture will be } \\
\text { located. The } \\
\text { transformation from a } \\
\text { situation of homogeneous } \\
\text { culture to a more } \\
\text { heterogeneous. }\end{array}$ & $\begin{array}{l}\text { Architecture that aims to } \\
\text { preserve local elements } \\
\text { that have been formed by } \\
\text { tradition and develop it } \\
\text { into a modern style. } \\
\text { Continuation of vernacular } \\
\text { architecture }\end{array}$ \\
\hline Design Ideas & $\begin{array}{l}\text { More emphasis on facade } \\
\text { or form, ornamentation as } \\
\text { a necessity. }\end{array}$ & $\begin{array}{l}\text { Ornaments are } \\
\text { complementary, do not } \\
\text { leave local values but can } \\
\text { serve community activities } \\
\text { inside. }\end{array}$ & $\begin{array}{l}\text { A more modern shape of } \\
\text { the design }\end{array}$ \\
\hline
\end{tabular}

\section{Study Functions and Facilities}

Resort Hotel will be designed as a lodging facility that can attract tourists to stay more than two nights at the resort hotel. This resort hotel is a three-star hotel, with minimal facilities as follows, 50 standard rooms with an area of $24 \mathrm{~m} 2$ / room, 3 suites with an area of 48 $\mathrm{m} 2$ / room, restaurant, cafe and bar, at least 1 recreation and sport facility, like swimming pool, there is drug store, travel agency, souvenir shop, office, minimarket, meeting rooms are available. By the requirements of three-star hotel classification.

\section{Location and Site}

Site located at the junction between Jamin Ginting Road and Udara Road which is the main route to the tourist destinations in North Sumatra and has an area of \pm 2.7 hectares. Its distance is about $70 \mathrm{~km}$ from the center of Medan. The population of Berastagi at this time numbered about 48.975 people, and about $90 \%$ of them are Karonese (Figure 1). 


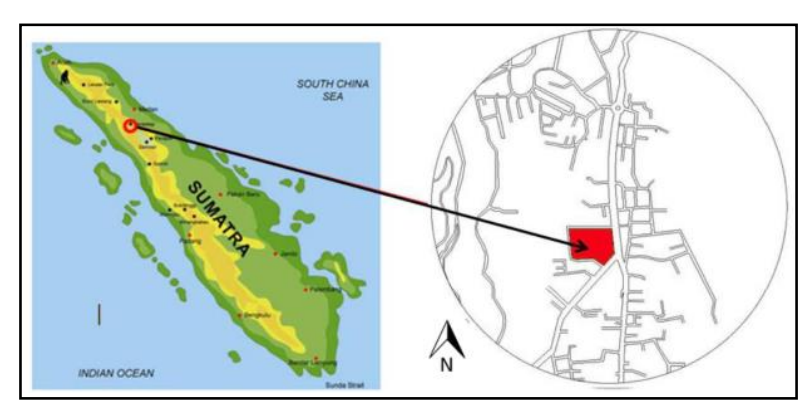

Figure 1. Location Map Berastagi

The design site has an area of \pm 2.7 hectares with applicable regulations around and the border of the site on Northern side is commercial shop, on Southern side is Udara Street, on East side is Jamin Ginting Street, and on West side is Sinar Alley.

\section{METHODOLOGY}

The methodology used is collecting data by field survey, interview, social mapping, literature study, and comparative study. The results of data collection were analyzed by the method of the design analysis method and then obtained the conclusion as outlined in the form of drawing sketch. The results of the analysis are processed into design and planning concepts in measurable working drawings in the technic of site plans, ground plan, elevation, views, sections, details, structural, mechanical, electrical, and perspective sketches.

\section{RESULTS AND DISCUSSION}

\section{Analysis of Land Use}

In the vicinity of the location, several functions that exist such as shops, markets, terminals, open spaces or parks, some residential neighborhoods. This location is considered to be a strategic location for making Resort Hotels considering it that is close to the existing facilities and has cold and comfortable weather conditions. It has 15 meters boulevard in Jamin Ginting Street and 6 meters artery road in Udara Street. Outside the land, there are several open spaces such as Gundaling and residents' strawberry gardens which can be used as agriculture tours (Figure 2).

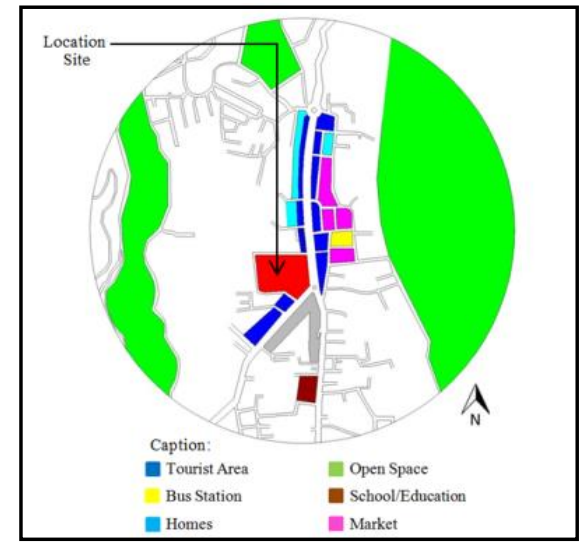

Figure 2. Land Use Analysis

\section{Analysis of Activity}

Users of resort hotel consist of visitors (domestic and foreign) and hotel management (employees and supervisor). The activities of visitors (guest) who stay or not stay can be seen in the picture below (Figure 3).

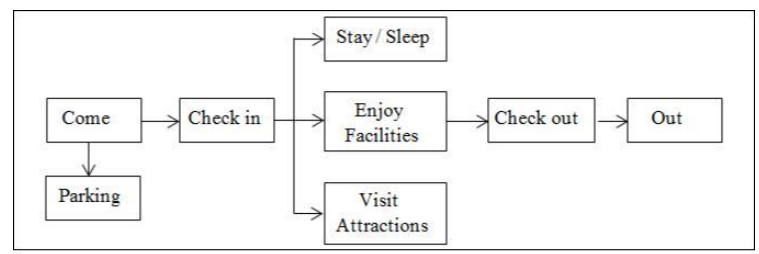

Figure 3. The Activities of Guests

The activities of hotel management (employees and supervisor) schematically can be seen in the picture below (Figure 4).

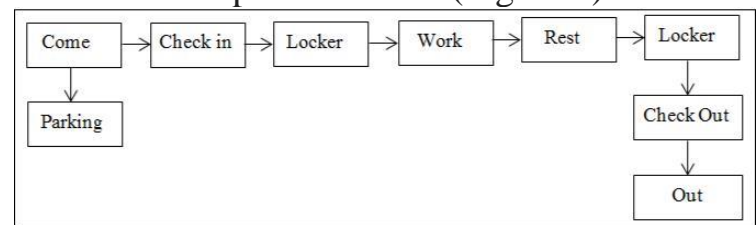

Figure 4. The Activities of Hotel Employee

\section{Basic Concept}

The basic concept used is the NeoVernacular Architecture. It is applied to apply local Karo culture. By used architecture as a design in modern architecture, the Hotel can attract to stay the tourists. The basic concept of hotel building design is the traditional house Siwaluh Jabu. Siwaluh Jabu has a form of eight spaces in one building which connected each other [3].

Siwaluh Jabu is inhabited by eight families which are symbolizing kinship and togetherness. Each family has a bedroom in their cubicle. They must remain in interlace in the dwelling to be designed, traditional house 
Siwaluh Jabu transformed into a form of place within the resort hotel to be built.

\section{Site Concept}

The road circulation of Hotel Resort Berastagi is on Jamin Ginting Road. Zones on the ground can be divided into 3 zones, such as private zones, semi-public zones, and public zones. The parking area is in front of the land so that it is easy to be accessed by visitors. The mass of the hotel is placed in the middle of it so the view to Gundaling can be the main attraction for visitors. Function rooms are in the middle because it is a public zone (Figure 5).

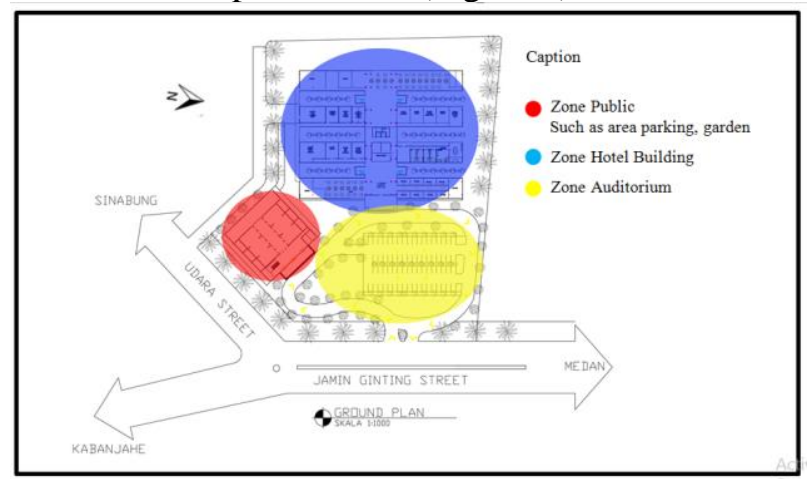

Figure 5. The concept of Main Building Façade

\section{Building and Appearances Concept}

The mass of this Hotel takes the concept of the Karo traditional house Siwaluh Jabu. Siwaluh means 8 (eight) and Jabu means families; so, it is building mass will be designed in form 8 buildings that are unified. In the scheme can be seen in one house, there is a shared space between the eight families. It is in the form of a kitchen and living room. This concept will be transformed so that it can be applied to hotel design this time. The hotel that will be designed will have eight towers that will be connected between each tower so that it looks like a custom Siwaluh Jabu house scheme. Simply put, the pattern of the Siwaluh Jabu traditional house in the Karo Tribe has three main spaces, namely, the Living Room, the Bedroom, and the kitchen which are used together with two families who have adjacent bedrooms (Figure 6).

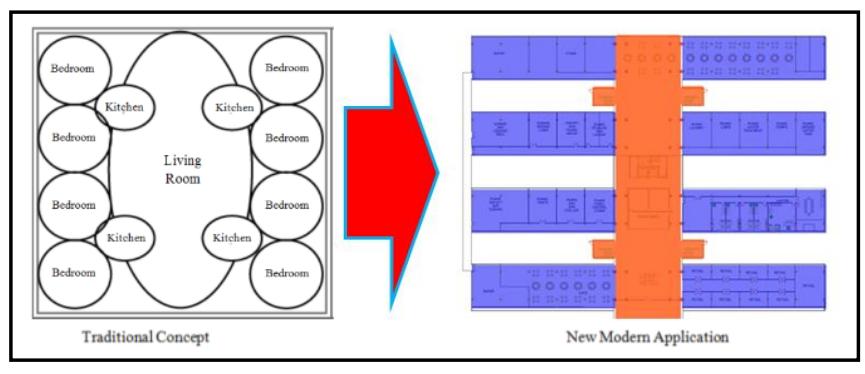

Figure 6. Concept Mass of the Building

To show more the concept of NeoVernacular will be made the cultural ornaments of the Karo tribe mixed with the existing materials in the present day. It is because of the original of traditional house Siwaluh Jabu very difficult to find in recent days. It is also to showcase the modern nuances of the building. The roof of the building also adopted from the roof shape of the traditional house of the Karo tribe. The combination of it and traditional house Geriten (one of the traditional buildings of the Karo tribe, also shaped like a Siwaluh Jabu but the form is much smaller) combined to make the characteristic of Karonese (Figure 7).

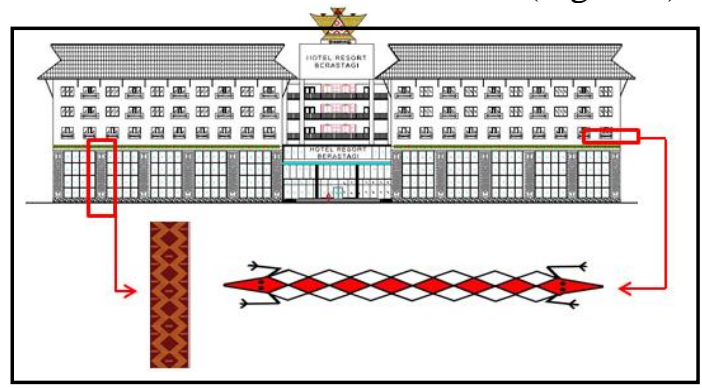

Figure 7. Facade Hotel

\section{Spatial and Arrangement Concept}

Hotel Resort Berastagi has eight towers by the principle of traditional house Siwaluh Jabu. On the first floor of the building consists of public spaces such as a lobby, restaurant, retail stores, service, and warehouse. On the second floor consists of semi-public such as management offices, facilities provided by the hotel such as swimming pool, spa, sauna, fitness center, and children's playground. While on the 3rd floor are hotel rooms that are already private (Figure 8).

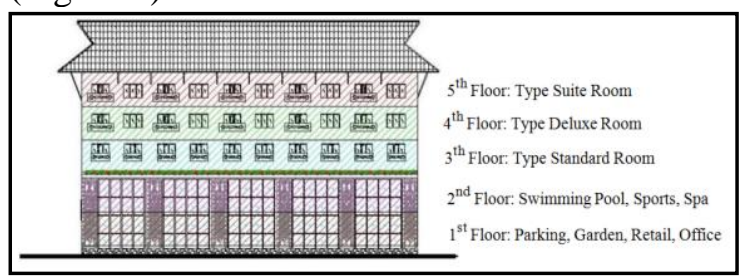

Figure 8. Spatial and Arrangement Concept 


\section{Building Structure Concept}

The main building support structure uses a rigid frame structure system. The rigid frame structure is still effective on a five-story building. Also, the structural supporting material also uses steel and reinforced concrete. Column dimensions are $0.8 \times 0.8 \mathrm{~m}$ and a beam $0.3 \times 0.5$ $\mathrm{m}$. Building foundation structure using pile a foundation system. The use of this foundation is due to the soft soil structure. The use of this foundation is very appropriate for soft soil structure [4].

\section{The utility of Air Condition Concept}

The air circulation system is related to the temperature that is very influential on the convenience of building users. To gain the comfort of these temperatures are used two air circulation system that is natural and artificial circulation. Artificial circulation, obtained by using an air conditioner that can adjust the room temperature by the chiller. It uses air conditioning in public and managers areas such as corridors, lobby, meeting rooms. Every module of the hotel uses the split AC (Air Condition) (Figure 9).

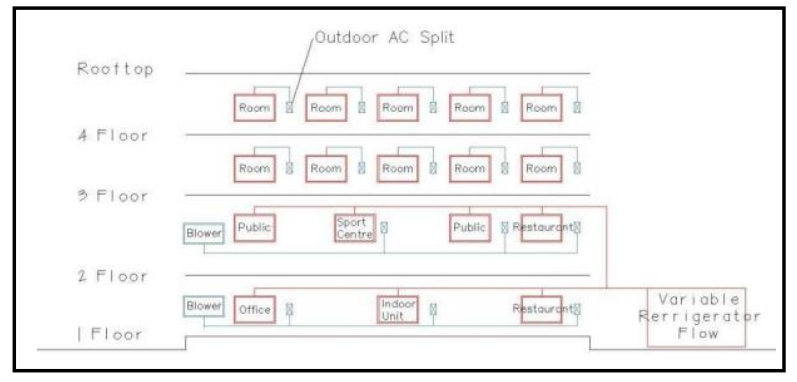

Figure 9. Air Condition Concept

\section{The Utility of Electricity Concept}

Electricity distribution comes from PLN ${ }^{1}$ which is channeled to the Distribution Panel (MDP). After going through the transformer, the flow is the Low Voltage Main Distribution Panel (LVMDP) and proceed to several sub-panels to be forwarded to all electrical devices in the building. For emergencies, a generator set is provided that will directly replace the electrical power from the primary source of the PLN that is disconnected (Figure 10).

\footnotetext{
${ }^{1}$ PLN (Perusahaan Listrik Negara) $=$ State Electricity Company
}

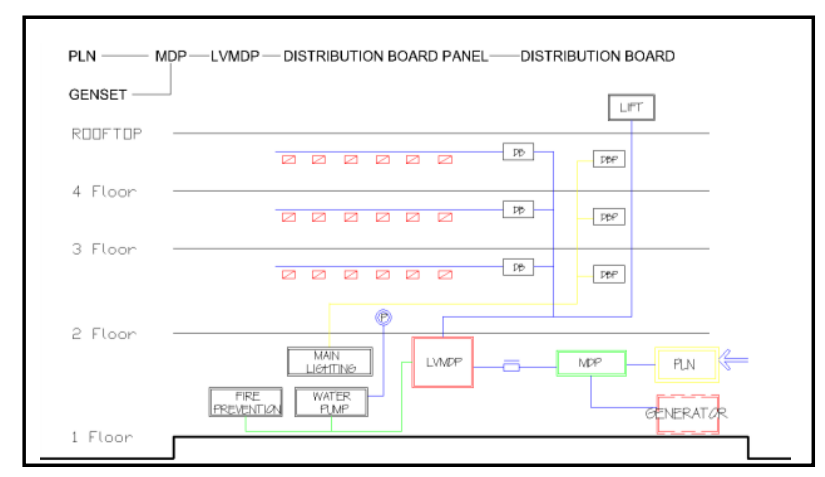

Figure 10. Electricity Concept

\section{Clean Water Plumbing Concept}

The primary source of clean water in this building is from the PDAM ${ }^{2}$ with the Up Feed Pumping System method that is it from the PDAM is pumped up and then immediately flowed to each floor of the building (Figure 11).

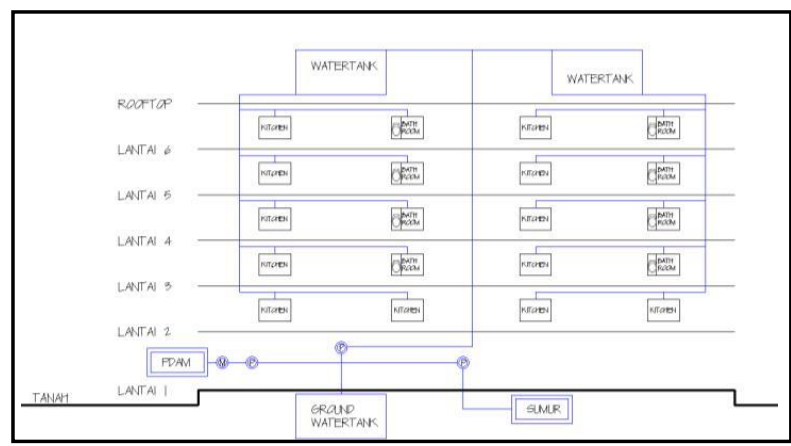

Figure 11. Clean Water Concept

\section{Gray Water and Black Water Plumbing Concept}

Black water containing solid dirt from the toilet is channeled to the septic tank. After going to the septic tank, it was absorbed into the infiltration well. Whereas gray water in the form of liquid comes from the room, small, urinal, sink, restaurant, directly discharged into the city water drain disposal using closed channels. While the rainwater will be continued by the gutter and down until the water channel is closed/immediately falls to the ground (Figure 12).

\footnotetext{
${ }^{2}$ PDAM (Perusahaan Daerah Air Minum) $=$ Local Water Company
} 


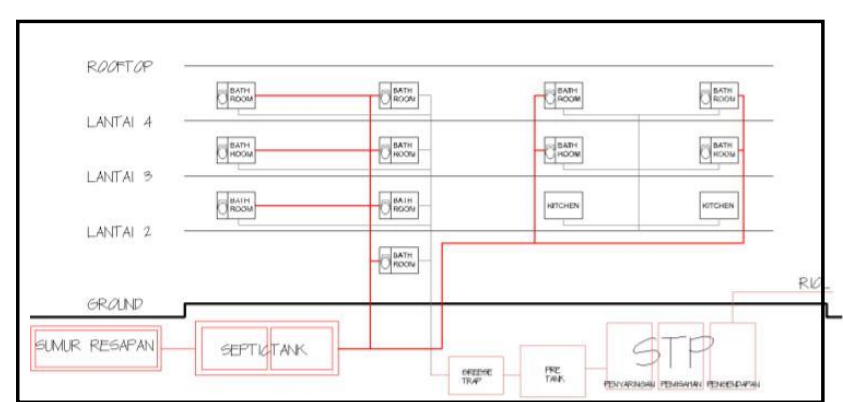

Figure 12. Water Plumbing Concept

\section{CONCLUSION}

This hotel designed in Berastagi has excellent natural potential such as a cold climate and view towards the mountains. With a threestar hotel classification, the number of rooms is 100 , and five different types of them can accommodate the visitors. To keep the cultural tour, the hotel applies the theme of NeoVernacular Architecture. The concept used is from the Siwaluh Jabu Traditional House, which is used in modern design. By using it is expected to keep the local wisdom of Berastagi and Karo. So in addition to nature tourism, the tourist can also enjoy cultural tourism especially the Karo tribe.

\section{Acknowledgment}

This article is written by researchers who are partly funded by Universitas Sumatera Utara and was given out as a donation to the government to preserve and improve the value of design, local wisdom, arts and ethnic.

\section{Daftar Pustaka}

W. Rutes \& R. Penner (1985) Hotel Planning and Design. New York: Watson Guptill.

Sitanggang, H (1991) Arsitektur Tradisional Batak Karo. Jakarta: Departemen Pendidikan dan Kebudayaan.

Brahma, P (1995) Karo dari Zaman ke Zaman. Medan: Ulih Saber.

Juwana, J. S (2005) Sistem Bangunan

Tinggi . Jakarta: Erlangga 